\title{
FAKTOR-FAKTOR YANG BERHUBUNGAN DENGAN KEIKUTSERTAAN IBU HAMIL DALAM PEMERIKSAAN VCT DI PUSKESMAS
}

\author{
Nurhayati \\ STIKes Fort De Kock, Bukittinggi \\ email : kheisa_yat@yahoo.com
}

Submitted: 05-12-2016, Reviewer: 07-12-2016, Accepted: 09-12-2016

Kasus HIV/AIDS menjadi masalah yang serius di kota Bukittinggi. Dari 7 puskesmas di Bukittinggi, Puskesmas Guguk Panjang merupakan puskesmas dengan Jumlah ibu hamil tertinggi yaitu 637 orang dan jumlah penderita HIV/AIDS sebanyak 95 orang. Tujuan penelitian untuk mengetahui hubungan pengetahuan, dukungan suami dan peran petugas kesehatan dengan keikutsertaan ibu hamil dalam pemeriksaan VCT di Puskesmas Guguk Panjang.Jenis penelitian deskriptif analitik dengan pendekatan cross sectional. Populasi adalah ibu hamil di Puskesmas Guguk Panjang tahun 2016, yaitu sebanyak 637 orang. Sampel berjumlah 46 orang, dengan tekhnik pengambilan sampel accidental sampling.

Hasil analisa univariat diketahui 58,7\% ibu hamil dengan pengetahuan rendah, 63\% dengan dukungan suami kurang baik, 54,3\% dengan peran petugas kesehatan baik, dan 56,5\% ibu hamil sudah melakukan pemeriksaan VCT. Hasil Analisa Bivariat diketahui ada hubungan antara pengetahuan, dukungan suami, dan peran petugas kesehatan dengan keikutsertaan ibu hamil dalam pemeriksaan VCT. pengetahuan ( $\mathrm{p}=0,023$ dan $\mathrm{OR}=5,455)$, dukungan suami $(\mathrm{p}=0,016$ dan $\mathrm{OR}=6,611)$ dan peran petugas kesehatan $(\mathrm{p}=0,000$ dan $\mathrm{OR}=69,000$ ). disimpulkan faktor tingkat pengetahuan, dukungan suami dan peran petugas kesehatan berpengaruh terhadap keikutsertaan ibu hamil dalam pemeriksaan VCT di Puskesmas Guguk Panjang.

\section{Kata kunci : Pengetahuan, Dukungan Suami, Peran Petugas Kesehatan,VCT}

HIV/AIDS cases be the most serious problem in Bukittinggi. Among 7 health centres in Bukittinggi, Guguk Panjang health center is the highest number of pregnant women is 637 peoples with HIV/AIDS patients as much as 95 peoples. Purpose of the research is to know relationship of mother knowledge, husband support, and role of health professionals with participation of pregnant women in examination of VCT in Guguk Panjang health centre in 2016. Type a descriptive analytic study with cross sectional approach. population of the research is pregnant women in Guguk Panjang health centre in 2016 as much as 637 peoples. Sample of the research as much as 46 peoples with sampling tachnique is accidental sampling. Results of univariate analysis is known 58,7\% pregnant women with the low knowledge, 63\% with husband support less well, 54,3\% with role of health professionals well, and 56,5\% pregnant women had check VCT. Results of bivariate analysis is known the relationship of mother knowledge, husband support, androle of health professionals with participation of pregnant woman in examination of VCT. knowledge $(\mathrm{p}=0,023$ and $\mathrm{OR}=5,455)$, husband support $(\mathrm{p}=0,016$ and $\mathrm{OR}=6,611)$ and role of helath professionals $(\mathrm{p}=0,000$ and $\mathrm{OR}=69,000)$. Level of knowledge can be inferred factors, support the husband and the role of health workers affect the participation of pregnant women in the examination at the health center VCT Guguk Panjang.

Keywords : Knowledge, Husband Support, Role Of Health Proffesionals, VCT 


\section{PENDAHULUAN}

Diseluruh dunia pada tahun 2013 ada 35 juta orang hidup dengan HIV meliputi 16 juta perempuan dan 3,2 juta anak berusia < 15 tahun. Jumlah infeksi baru HIV pada tahun 2013 sebesar 2,1 juta yang terdiri dari 1,9 juta dewasa dan 240.000 anak berusia < 15 tahun. Jumlah kematian akibat AIDS sebanyak 1,5 juta yang terdiri dari 1,3 juta dewasa dan 190.000 anak berusia < 15 tahun (WHO, 2013).

Di Indonesia, HIV/ AIDS pertama kali ditemukan di provinsi bali pada tahun 1987 . Hingga saat ini HIV/AIDS sudah menyebar di 386 kabupaten/ kota di seluruh provinsi di Indonesia. Kasus HIV di Indonesia menunjukan kecenderungan peningkatan dari tahun ke tahun sejak pertama kali di laporkan tahun 1987. Sebaliknya Jumlah kasus AIDS menunjukan kecenderungan meningkat secara lambat sejak tahun 2012 jumlah kasus AIDS mulai turun. Jumlah kumulatif kasus penderita HIV dari tahun 1987 sampai september 2014 sebanyak 150 . 296 orang, sedangkan total kumulatif kasus AIDS sebanyak 55.799 orang (Kemenkes RI, 2014).

Provinsi Sumatera Barat berada pada peringkat ke- 13, jumlah kasus HIV/ AIDS tertinggi di Indonesia dengan jumlah kasus HIV sebanyak 1.136 kasus sedangkan kasus AIDS sebanyak 952 kasus (Kemenkes RI, 2014).

Bukittinggi merupakan salah satu kota yang ada di provinsi Sumatera Barat. Kasus HIV/AIDS menjadi masalah yang paling serius di kota Bukittinggi. Bukittinggi berada pada peringkat kedua tertinggi jumlah penderita HIV/AIDS di Sumatera Barat pada tahun 2014 setelah padang. Dengan jumlah pasien yang terdaftar di salah satu rumah sakit di Bukittinggi berjumlah 150 orang (Dinkes Sumbar, 2014).

Resiko penularan HIV sebenarnya tidak hanya terbatas pada sub populasi yang berprilaku resiko tinggi, tetapi juga pada pasangan atau istrinya, bahkan anaknya. Tanpa upaya khusus, diperkirakan pada akhir tahun 2016 akan terjadi penularan HIV secara kumulatif pada lebih dari 26.977 anak yang dilahirkan dari ibu yang terinfeksi HIV. Para ibu ini sebagian besar tertular dari suaminya (Kemenkes RI, 2013).

Berdasarkan kebijakan Menteri Kesehatan Nomor 21 Tahun 2013 Tentang Penanggulangan HIV dan AIDS pasal 17 disebutkan bahwa semua ibu hamil yang melakukan pemeriksaan kehamilannya diharuskan mengikuti pemeriksaan diagnostik HIV dengan tes dan konseling (VCT) sebagai upaya pencegahan dan penularan HIV dari ibu ke anak yang dikandungnya (Kemenkes, 2013).

Strategi VCT merupakan inti dari semua upaya pencegahan dan penanggulangan HIV/AIDS di dunia. Beberapa penelitian menegaskan bahwa pemanfaatan VCT antenatal oleh ibu hamil masih rendah. Penelitian lain juga menyatakan bahwa hambatan yang dirasakan untuk VCT seperti stigma sosial, kurangnya dukungan pasangan laki- laki dan takut mengetahui status HIV positif serta kurangnya peran petugas kesehatan (Zinash, 2011).

Prilaku menerima dan menolak VCT yang dilakukan oleh ibu hamil dipengaruhi oleh beberapa faktor. Menurut Skinner dalam Notoatmodjo (2007), menyebutkan bahwa faktor - faktor yang membedakan prilaku, yaitu faktor internal dan faktor eksternal. Dimana faktor internal tersebut merupakan faktor yang berhubungan langsung dengan pelaku yaitu usia, jenis kelamin, pendidikan, pekerjaan. Sedangkan faktor eksternal adalah faktor dari luar (lingkungan) yang mempengaruhi misalnya jarak tempat pelayanan ataupun peran keluarga (Notoatmodjo, 2007).

Penelitian yang dilakukan oleh Charunia (2015) menyatakan bahwa tingkat 
pengetahuan ibu tentang HIV/AIDS berhubungan dengan minat ibu hamil melakukan Voluntary Counseling and Testing (VCT). dan penelitian yang dilakukan oleh Indah (2015) menyatakan bahwa peran bidan berhubungan dengan minat ibu hamil melakukan Voluntary Counseling and Testing (VCT).

Data dari Dinas Kesehatan Kota Bukittinggi tahun 2015, dari 7 puskesmas yang yang terdapat di Kota Bukittinggi, puskesmas Guguk Panjang merupakan puskesmas dengan Jumlah ibu hamil tertinggi dengan jumlah 637 orang. Jumlah penderita HIV/AIDS di Puskesmas Guguk Panjang Kota Bukittinggi pada tahun 2015 sebanyak 95 orang.

Berdasarkan hasil survey awal yang dilakukan oleh peneliti pada tanggal 22 februari 2016 dengan melakukan wawancara kepada 10 orang ibu hamil yang berkunjung di Puskesmas Guguk Panjang Kota Bukittinggi didapatkan hasil bahwa 7 orang tidak mengetahui dengan baik tentang HIV/AIDS dan saat kunjungan tidak ditemani oleh suami serta belum pernah melakukan pemeriksaan VCT.

\section{METODE PENELITIAN}

Jenis penelitian ini adalah Deskriptif Analitik dengan desain penelitiancross sectional. Penelitian ini dilakukan di Puskesmas Guguk Panjang Bukittinggi pada Bulan Mei - Juni 2016. Populasi dalam penelitian ini adalah seluruh ibu hamil dengan teknik sampel adalah accidental sampling dengan jumlah sampel sebanyak 46 orang. Data dikumpulkan melalui kuesioner dan dari data sekunder Puskesmas. Kemudian data di analisis dengan uji statistik chi-square dengan derajat kepercayaan $\alpha=0,05$.

\section{HASIL DAN PEMBAHASAN}

Hasil penelitian yang dilakukan di Puskesmas Guguk Panjang Bukittinggi Tahun 2016 tentang faktor-faktor yang berhubungan dengan keikutsertaan ibu hamil dalam pemeriksaan VCT di Wilayah Kerja Puskesmas Guguk Panjang. Data dianalisis secara univariat dan bivariat. Adapun hasil dari penelitian ini adalah sebagai berikut

\section{Hasil Univariat}

\section{a. Pengetahuan}

Tabel 1

Distribusi Frekuensi Pengetahuan pada Ibu Hamil di Puskesmas Guguk Panjang

\begin{tabular}{clcc}
\hline No & Pengetahuan & F & \% \\
1. & Rendah & 27 & 58,7 \\
2. & Tinggi & 19 & 41,3 \\
& Jumlah & 46 & 100 \\
\hline
\end{tabular}

Berdasarkan tabel 1 dapat dilihat dari 46 ibu hamil, sebagian besar responden memiliki pengetahuan Rendah sebanyak 27 responden $(58,7 \%)$ dan pengetahuan tinggi sebanyak 19 responden $(41,3 \%)$.

Pengetahuan adalah hasil "tahu" dan ini terjadi setelah orang melakukan penginderaan terhadap suatu objek tertentu. Penginderaan itu terjadi melalui panca indera manusia yakni indera penglihatan, pendengaran, penciuman, rasa dan raba. Sebagian besar penginderaan manusia diperoleh melalui mata dan telinga. Pengetahuan kognitif merupakan doamin yang sangat penting dalam membentuk tidakan seseorang. Perilaku yang didasarkan pengetahuan, kesadaran, dan sikap positif lebih langgeng dari pada perilaku yang tidak didasarkan oleh pengetahuan (Notoatmodjo, 2010).

Pengetahuan yang baik sangat mempengaruhi pola pikir seseorang, karena semakin tinggi pengetahuan seseorang semakin tinggi pula kemampuan dan kesadaran mereka dalam menerima informasi serta menerapkannya dengan mudah dalam kehidupan sehari- hari.

Hasil penelitian ini sejalan dengan penelitian yang dilakukan oleh Ayu Wulan Sari (2014) yang berjudul Faktor - Faktor yang berhubungan dengan Niat Ibu Hamil Untuk Memanfaatkan Layanan VCT (Voluntary Counseling And Testing) di Wilayah Kerja Puskesmas Ciputat Kota Tangerang Selatan dimana didapat sebanyak 70 responden $(92,1 \%)$ memiliki pengetahuan rendah.

Menurut asumsi peneliti masih banyak nya ditemukan ibu hamil yang memiliki pengetahuan rendah yang tidak melakukan pemeriksaan VCT karena masih rendah nya tingkat pendidikan responden yang sebagian besar berpendidikan SMA. Karena biasanya tingkat pengetahuan erat 
kaitanya dengan tingkat pendidikan seseorang, sehingga menimbulkan anggapan - anggapan yang keliru tentang pentingnya melakukan pemeriksaan VCT selama kehamilan.

Menurut asumsi peneliti banyaknya responden yang memiliki pengetahuan yang rendah tentang pemeriksaan VCT disebabkan oleh mereka kurang aktif dalam mencari informasi tentang pemeriksaan Voluntary Counseling and Testing (VCT) bagi ibu hamil, selain itu mereka juga kurang melakukan interaksi komunikasi kepada petugas kesehatan, padahal informasi - informasi terkait dengan pelayanan VCT dapat dengan mudah didapatkan di pelayanan kesehatan seperti posyandu dan puskesmas.

\section{b. Dukungan Suami}

Tabel 2

Distribusi Frekuensi Dukungan Suami pada Ibu Hamil di Puskesmas Guguk Panjang

\begin{tabular}{clcc}
\hline No & Dukungan suami & F & \% \\
1. & KurangBaik & 29 & 63,0 \\
2. & Baik & 17 & 37,0 \\
& Jumlah & 46 & 100 \\
\hline
\end{tabular}

Berdasarkan tabel 5.2 dapat dilihat dari 46 ibu hamil, sebagian besar responden memiliki dukungan suami kurang baik yaitu sebanyak 29 responden $(63,0 \%)$ dan yang mendapat dukungan suami dengan kategori baik sebanyak 17 responden $37,0 \%)$.

Dukungan suami adalah respon suami terhadap kehamilan istri yang dapat menyebabkan adanya ketenangan batin dan perasaan senang dalam diri istri. Suami adalah orang pertama dan utama dalam memberi dorongan kepada istri sebelum pihak lain turut memberi dorongan, dukungan, dan perhatian seorang suami terhadap istri yang sedang hamil yang akan membawa dampak positif bagi ibu dan bayi (Franchicandra, 2010, p.3).

Hasil penelitian ini sejalan dengan penelitian yang telah dilakukan oleh Titi Legiati, dkk (2012) yang berjudul Prilaku Ibu Hamil Untuk Tes HIV di Kelurahan
Bandarharjo dan Tanjung Mas Kota Semarang dimana didapatkan responden 42,8\% tidak mendapat dukungan suami.

Menurut asumsi peneliti banyak nya ditemukan ibu hamil yang tidak mendapatkan dukungan suami disebabkan oleh kurang nya pemahaman suami tentang manfaat dan pentingnya melakukan pemeriksaan VCT baik bagi suami dan bagi ibu hamil. Selain itu kurang nya dukungan suami juga disebabkan oleh tingkat pekerjaan suami yang menyebabkan kurangnya waktu untuk memberikan dorongan pada ibu hamil atau menemani ibu hamil ke tempat pelayanan kesehatan.

\section{c. Peran Petugas Kesehatan}

Tabel 3

Distribusi Frekuensi Peran Petugas kesehatan pada Ibu Hamil di Puskesmas Guguk Panjang

\begin{tabular}{llcc}
\hline No & \multicolumn{1}{c}{ Peran } & F & \% \\
& Petugas kesehatan & & \\
1. & KurangBaik & 21 & 45,7 \\
2. & Baik & 25 & 54,3 \\
& Jumlah & 46 & 100 \\
\hline
\end{tabular}

Berdasarkan tabel 3 dapat dilihat dari $46 \mathrm{ibu}$ hamil, sebagian besar responden dengan peran petugas kesehatan baik sebanyak 25 responden $(54,3 \%)$ dan responden dengan peran petugas kesehatan kurang baik sebanyak 21 responden $(45,7 \%)$.

Tenaga kesehatan khususnya bidan sangat berperan dalam memberikan dukungan pada ibu hamil. Bidan sebagai tempat mencurahkan segala isi hati dan kesulitannya dalam menghadapi kehamilan dan persalinan. Tenaga kesehatan harus mampu mengenali keadaan yang terjadi di sekitar ibu hamil. Hubungan yang baik saling mempercayai dapat memudahkan bidan/ tenaga kesehatan dalam memberikan pendidikan dalam kesehatan (Kusmiati, 2008, Pp. 137).

Hasil penelitian ini sama dengan penelitian yang di lakukan oleh Indah, Galuh Pramita (2015) dengan judul Hubungan Peran Bidan Dengan Kepatuhan Pemeriksaan VCT (VoluntaryCounseling And Testing) pada Ibu Hamil di Wilayah 
Kerja Puskesmas Gitik Kabupaten Banyuwangi menunjukan 25 responden $(83 \%)$ dengan peran petugas kesehatan baik.

Menurut asumsi peneliti banyak nya ibu hamil yang kurang mendapatkan peran petugas kesehatan dikarenakan petugas kesehatan jarang melakukan jarang melakukan penyuluhan kepada ibu hamil tentang pemeriksaan VCT dan kurang nya petugas laboratorium yang bertugas melakukan pemeriksaaan VCT kepada ibu hamil yang berkunjung serta petugas kesehatan tidak pernah memberikan brosur kepada ibu hamil yang berkaitan dengan penting nya melakukan pemeriksaan VCT. Dukungan dan peran petugas kesehatan sangat berpengaruh agar ibu hamil bersedia atau tertarik untuk melakukan pemeriksaan VCT.

\section{d. Keikutsertaan Pemeriksaan VCT Tabel 4}

\section{Distribusi Frekuensi Keikutsertaan Ibu}

Hamil dalam Pemeriksaan VCT di Puskesmas Guguk Panjang

\begin{tabular}{clcc}
\hline No & Pemeriksaan Vct & F & \% \\
1. & TidakMelakukan & 20 & 43,5 \\
2. & Melakukan & 26 & 56,5 \\
& Jumlah & 46 & 100
\end{tabular}

Berdasarkan tabel 4 dapat dilihat bahwa dari 46 ibu hamil yang tidak melakukan pemeriksaan VCT sebanyak 20 responden $(43,5 \%)$ dan yang melakukan pemeriksaan VCT sebanyak 26 responden $(56,5 \%)$.

Konseling dan testing sukarela atau yang dikenal sebagai VCT adalah proses konseling pra testing, konseling post testing, dan testing HIV secara sukarela yang bersifat rahasia dan secara lebih dini membantu orang mengetahui status HIV yang penting untuk pencegahan dan perawatannya (Anastasya, 2010).

VCT (Voluntary Counseling and Testing) bertujuan untuk memberikan informasi tentang HIV/AIDS, mencegah penularan HIV, memberikan dukungan moral, informasi, serta dukungan lainnya kepada ODHA, keluarga dan lingkungannya (Nursalam, 2014, p. 76).
Hasil penelitian ini sejalan dengan penelitian yang dilakukan oleh Titi Legiati, dkk (2012) yang berjudul Prilaku Ibu Hamil Untuk Tes HIV di Kelurahan Bandarharjo dan Tanjung Mas Kota Semarang menunjukan bahwa sebagian besar ibu hamil $(51,1 \%)$ telah melakukan pemeriksaan VCT.

Menurut asumsi peneliti masih banyaknya ditemukan ibu hamil yang belum melakukan pemeriksaan VCT disebabkan karena pengetahuan responden yang masih rendah sehingga kurang nya pemahaman tentang manfaat pemeriksaan VCT dan persepsi yang keliru tentang pemeriksaan VCT, kurangnya dukungan dari suami, serta peran petugas kesehatan yang kurang aktif dalam memberikan penyuluhan kepada ibu hamil tentang pentingnya melakukan pemeriksaan VCT.

\section{Hasil Bivariat}

\section{a. Tingkat Pengetahuan dengan Keikutsertaan ibu Hamil dalam pemeriksaan VCT}

\section{Tabel 5}

\section{Hubungan Tingkat Pengetahuan dengan keikutsertaan ibu hamil dalam pemeriksaan VCT Di Puskesmas Guguk Panjang}

\begin{tabular}{|c|c|c|c|c|c|c|c|c|c|}
\hline \multirow{4}{*}{ NO } & \multirow{4}{*}{$\begin{array}{c}\text { PENGETA } \\
\text { HUAN }\end{array}$} & \multicolumn{4}{|c|}{ PEMERIKSAAN VCT } & \multicolumn{2}{|c|}{ TOTAL } & \multirow{4}{*}{$\begin{array}{c}\text { P } \\
\text { VAL } \\
\text { UE }\end{array}$} & \multirow{4}{*}{$\mathbf{O R}$} \\
\hline & & \multirow{2}{*}{\multicolumn{2}{|c|}{$\begin{array}{c}\text { TidakMelak } \\
\text { ukan }\end{array}$}} & \multicolumn{2}{|c|}{ Melakukan } & \multirow{3}{*}{$\mathrm{N}$} & \multirow{3}{*}{$\%$} & & \\
\hline & & & & & & & & & \\
\hline & & $\mathrm{n}$ & $\%$ & $\mathrm{n}$ & $\%$ & & & & \\
\hline 1 & Rendah & 16 & 59,3 & 11 & 40,7 & 27 & 100 & & \\
\hline \multirow[t]{2}{*}{2} & Tinggi & 4 & 21,1 & 15 & 78,9 & 19 & 100 & 0,023 & 5,455 \\
\hline & Total & 20 & 43,5 & 26 & 56,5 & 46 & 100 & & \\
\hline
\end{tabular}

Berdasarkan tabel 5 terlihat bahwa dari 27 responden yang memiliki pengetahuan rendah sebanyak 16 responden $(59,3 \%)$ tidak melakukan pemeriksaan VCT. setelah uji statistik didapat $\mathrm{p}$ value $=$ $0,023(\mathrm{P} \leq 0,05)$ ini berarti ada hubungan antara tingkat pengetahuan dengan keikutsertaan ibu hamil dalam pemeriksaan VCT di Puskesmas Guguk Panjang Kota Bukittinggi.

Berdasarkan jurnal internasional didapatkan hasil penelitian ini sejalan dengan penelitian yang dilakukan oleh Abebaw Dimissie (2009) yang berjudul Determinants Of Acceptance Of Voluntary 
HIV Testing Among Antenatal Clinic Attendees At Dil Chora Hospital, Dire Dawa, East Ethiopia yang menyatakan ada hubungan yang signifikan antara tingkat pengetahuan dengan status pemeriksaan VCT pada ibu hamil.

$$
\text { Berdasarkan observasi yang }
$$
didapatkan dari jurnal ditemukan hasil penelitian sama dengan penelitian yang telah dilakukan oleh Rizki Nur Vitrasari (2014) yang berjudul Hubungan Antara Tingkat Pengetahuan,Sikap tentang Penyakit Menular Seksual (PMS) dan Motivasi Bidan Dengan Kesediaan Melakukan Tes Prevention Of Mother To child Of HIV Transmission pada Ibu Hamil Di Puskesmas Campurejo Kota Kediri, dari hasil penelitian tersebut didapatkan nilai $\mathrm{p}$ value $=0,042 \quad \mathrm{OR}=8,60$ yaitu ada hubungan yang signifikan antara tingkat pengetahuan dengan status pemeriksaan VCT pada ibu hamil.

Menurut asumsi peneliti banyaknya responden yang memiliki pengetahuan yang rendah tentang pemeriksaan VCT disebabkan oleh mereka kurang aktif dalam mencari informasi tentang pemeriksaan Voluntary Counseling and Testing (VCT) bagi ibu hamil, selain itu mereka juga tidak memahami tentang pentingnya melakukan pemeriksaan VCT dan manfaat yang didapatkan ibu hamil apabila melakukan pemeriksaan VCT saat kehamilan. Selain itu responden juga kurang melakukan interaksi komunikasi kepada petugas kesehatan, padahal informasi - informasi terkait dengan pelayanan VCT dapat dengan mudah didapatkan di pelayanan kesehatan seperti posyandu dan puskesmas.

\section{b. Dukungan Suami dengan Keikutsertaan ibu Hamil dalam pemeriksaan VCT}

Tabel 6

Hubungan Dukungan Suami dengan keikutsertaan ibu hamil dalam pemeriksaan VCT Di Puskesmas Guguk Panjang

\begin{tabular}{|c|c|c|c|c|c|c|c|c|c|}
\hline \multirow{4}{*}{$\begin{array}{l}\mathbf{N} \\
\mathbf{O}\end{array}$} & \multirow{4}{*}{$\begin{array}{c}\text { DUKUNGA } \\
\text { NSUAMI }\end{array}$} & \multicolumn{4}{|c|}{ PEMERIKSAAN VCT } & \multicolumn{2}{|c|}{ TOTAL } & \multirow{4}{*}{$\begin{array}{c}\mathbf{P} \\
\text { VALU } \\
\mathbf{E}\end{array}$} & \multirow{4}{*}{$\mathbf{O R}$} \\
\hline & & \multirow{2}{*}{\multicolumn{2}{|c|}{$\begin{array}{l}\text { TidakMelak } \\
\text { ukan }\end{array}$}} & \multirow{2}{*}{\multicolumn{2}{|c|}{ Melakukan }} & \multirow{3}{*}{$\mathrm{N}$} & \multirow{3}{*}{$\%$} & & \\
\hline & & & & & & & & & \\
\hline & & $\mathrm{n}$ & $\%$ & $\mathrm{n}$ & $\%$ & & & & \\
\hline 1 & KurangBaik & 17 & 58,6 & 12 & 41,4 & 29 & 100 & & \\
\hline 2 & Baik & 3 & 17,6 & 14 & 82,4 & 17 & 100 & 0,016 & 6,611 \\
\hline & Total & 20 & 43,5 & 26 & 56,5 & 46 & 100 & & \\
\hline
\end{tabular}

Berdasarkan tabel 6 terlihat bahwa dari 29 responden yang kurang mendapat dukungan suami sebanyak 17 responden $(58,6 \%)$ tidak melakukan pemeriksaan VCT. setelah uji statistik didapat $\mathrm{P}$ value $=$ $0,016(\mathrm{P} \leq 0,05)$ ini berarti ada hubungan yang bermakna antara dukungan suami dengan keikutsertaan ibu hamil dalam pemeriksaan VCT di Puskesmas Guguk Panjang Kota Bukittinggi tahun 2016.

Dukungan suami adalah respon suami terhadap kehamilan istri yang dapat menyebabkan adanya ketenangan batin dan perasaan senang dalam diri istri. Suami adalah orang pertama dan utama dalam memberi dorongan kepada istri sebelum pihak lain turut memberi dorongan, dukungan, dan perhatian seorang suami terhadap istri yang sedang hamil yang akan membawa dampak positif bagi ibu dan bayi ( Franchicandra, 2010, p.3).

Berdasarkan jurnal internasional didapatkan hasil penelitian ini tidak sejalan dengan penelitian yang dilakukan oleh Abebaw Dimissie (2009) yang berjudul Determinants Of Acceptance Of Voluntary HIV Testing Among Antenatal Clinic Attendees At Dil Chora Hospital, Dire Dawa, East Ethiopia yang menyatakan bahwa tidak ada hubungan yang signifikan antara dukungan suami dengan status pemeriksaan VCT pada ibu hamil.

Penelitian ini sejalan dengan penelitian yang dilakukan oleh Dan penelitian oleh Titi Legiati, dkk (2012) yang berjudul Prilaku Ibu Hamil Untuk Tes HIV di Kelurahan Bandarharjo dan Tanjung Mas Kota Semarang didapatkan nilai $\mathrm{p}$ value $=0,000$ yaitu ada hubungan yang signifikan antara dukungan suami dengan pemeriksaan VCT pada ibu hamil.

Menurut asumsi peneliti kurangnya dukungan suami terhadap pelaksanaan pemeriksaan VCT disebabkan oleh tingkat pekerjaan suami yang menyebabkan kurangnya perhatian dan waktu untuk memberikan dukungan atau motivasi kepada ibu hamil untuk melakukan pemeriksaan VCT selama kehamilan dan mengantar ibu hamil memeriksakan kehamilan ke fasilitas kesehatan, ibu hamil lebih banyak di temani oleh keluarga 
ataupun teman. Suami tidak memiliki cukup pengetahuan mengenai pemeriksaan VCT dan ditemukan banyak suami yang belum melakukan pemeriksaan VCT.

\section{c. Peran Petugas Kesehatan dengan Keikutsertaan ibu Hamil dalam pemeriksaan VCT}

\section{Tabel 7}

\section{Hubungan Peran Petugas Kesehatan dengan keikutsertaan ibu hamil dalam pemeriksaan VCT Di Puskesmas Guguk} Panjang

\begin{tabular}{|c|c|c|c|c|c|c|c|c|}
\hline \multirow{4}{*}{ No } & \multirow{4}{*}{$\begin{array}{c}\text { PERANTE } \\
\text { NAGAKES } \\
\text { EHATAN }\end{array}$} & \multicolumn{4}{|c|}{ PEMERIKSAAN VCT } & \multicolumn{2}{|c|}{ TOTAL } & \multirow{4}{*}{$\begin{array}{c}\text { P } \\
\text { VALU } \\
\mathbf{E}\end{array}$} \\
\hline & & \multirow{2}{*}{\multicolumn{2}{|c|}{$\begin{array}{c}\text { TidakMelak } \\
\text { ukan }\end{array}$}} & \multirow{2}{*}{\multicolumn{2}{|c|}{ Melakukan }} & & & \\
\hline & & & & & & $\mathrm{N}$ & $\%$ & \\
\hline & & $\mathrm{n}$ & $\%$ & $\mathrm{n}$ & $\%$ & & & \\
\hline 1 & KurangBaik & 18 & 85,7 & 3 & 14,3 & 21 & 100 & \\
\hline \multirow[t]{2}{*}{2} & Baik & 2 & 8,0 & 23 & 92,0 & 25 & 100 & \\
\hline & Total & 20 & 43,5 & 26 & 56,5 & 46 & 100 & \\
\hline
\end{tabular}

Berdasarkan tabel 7 terlihat bahwa dari 25 responden dengan peran petugas kesehatan baik sebanyak 23 responden $(92,0 \%)$ melakukan pemeriksaan VCT. setelah uji statistik didapat $\mathrm{P}$ value $=0,000$ ( $\mathrm{P} \leq 0,05)$ ini berarti ada hubungan antara peran petugas kesehatan dengan keikutsertaan ibu hamil dalam pemeriksaan VCT di Puskesmas Guguk Panjang Kota Bukittinggi tahun 2016.

Peran petugas kesehatan adalah suatu kegiatan yang diharapkan dari seorang petugas kesehatan yang memberikan pelayanan kesehatan kepada masyarakat untuk meningkatkan derajat kesehatan masyarakat (Setiadi, 2008, p.20).

Hasil penelitian ini sama dengan penelitian yang dilakukan oleh Rizki Nur Vitrasari (2014) yang berjudul Hubungan Antara Tingkat Pengetahuan,Sikap tentang Penyakit Menular Seksual (PMS) dan Motivasi Bidan Dengan Kesediaan Melakukan Tes Prevention Of Mother To child Of HIV Transmission pada Ibu Hamil Di Puskesmas Campurejo Kota Kediri, dari hasil penelitian tersebut didapatkan nilai $\mathrm{p}$ value $=0,012$ OR $=27,58$ yaitu ada hubungan yang signifikan antara dukungan petugas kesehatan dengan status pemeriksaan VCT pada ibu hamil.

Dan penelitian Titi Legiati, dkk (2012) yang berjudul Prilaku Ibu Hamil Untuk Tes HIV di Kelurahan Bandarharjo dan Tanjung Mas Kota Semarang didapatkan nilai $\mathrm{p}$ value $=0,000$ yang menyatakan ada hubungan yang signifikan antara dukungan petugas kesehatan dengan status pemeriksaan VCT pada ibu hamil.

Pada hasil penelitian ini, peneliti menemukan responden yang memiliki peran petugas kesehatan kurang baik tidak melakukan pemeriksaan VCT, pada saat wawancara responden mengatakan bahwa responden cukup mendapatkan konseling maupun penyuluhan yang diberikan petugas kesehatan kepada ibu hamil tentang pentingnya pemeriksaan VCT, namun petugas kesehatan tidak pernah memberikan brosur kepada ibu hamil sehingga ibu hamil kurang termotivasi untuk melakukan pemeriksaan VCT. Selain itu petugas laboratotium yang sering tidak ada ditempat saat ibu hamil ingin melakukan pemeriksaan VCT.

Menurut asumsi peneliti responden yang melakukan pemeriksaan VCT sangat dipengaruhi oleh peran dari petugas kesehatan, khususnya bidan. Sosialisasi pemeriksaan VCT pada ibu hamil sangat penting, mengingat bidan sangat dekat dengan ibu hamil. Ibu hamil akan melakukan tes VCT karena anjuran petugas kesehatan, khsuusnya para bidan. Peran petugas kesehatan yang baik yaitu dalam memberikan informasi - informasi HIV/AIDS secara lengkap dan pentingnya melakukan pemeriksaan VCT bagi ibu hamil diberikan sampai ibu hamil memahami dan memberikan izinnya untuk dilakukan pemeriksaan VCT.

\section{SIMPULAN}

Berdasarkan data dan hasil penelitian maka dapat disimpulkan bahwa sebanyak 27 responden $(58,7 \%)$ memiliki pengetahuan rendah, 29 responden $(63,0 \%)$ mendapat dukungan suami kurang baik, 25 responden $(54,3 \%)$ ibu hamil dengan peran petugas kesehatan baik dan 26 responden 
$(56,5 \%)$ ibu hamil melakukan pemeriksaan VCT. Oleh karena itu, diperoleh ada hubungan antara tingkat pengetahuan dengan keikutsertan ibu hamil dalam pemeriksaan VCT dengan nilai $\mathrm{p}=0,023$ ( $\mathrm{p} \leq 0,05)$ dan OR yaitu 5,455, ada hubungan antara dukungan suami dengan keikutsertan ibu hamil dalam pemeriksaan VCT dengan nilai $p=0,016(p \leq 0,05)$ dan OR yaitu 6,611 dan ada hubungan antara peran petugas kesehatan dengan keikutsertan ibu hamil dalam pemeriksaan VCT. Nilai $p=0,000(p \leq 0,05)$ dan OR yaitu 69,000 .

\section{SARAN}

Hasil penelitian ini diharapkan dapat menambah wawasan yang luas tentang pemeriksaan VCT (Voluntary Counseling And testing) pada ibu hamil dan peneliti menyarankan agar petugas kesehatan melibatkan peran serta suami untuk mengingatkan ibu hamil untuk ikut dalam melakukan pemeriksaan VCT.Penelitian ini juga diharapkan dapat memberikan manfaat khususnya kepada ibu hamil untuk melakukan pemeriksaan VCTselama kehamilan dan menambah minat dan wawasan ibu tentang pentingnya melakukan pemeriksaan VCT pada ibu hamil.

\section{UCAPAN TERIMA KASIH}

Terima kasih kepada segenap jajaran Puskesmas Guguk Panjang atas dukungan dalam penelitian ini, serta responden yang telah ikut berartisipasi dalam melakukan penelitian. Selanjutnya, terima kasih kepada Institusi dan rekan-rekan yang telah memberi saran dan masukan atas penelitian ini, sehingga penelitian ini dapat digunakan untuk penelitian selanjutnya

\section{DAFTAR PUSTAKA}

Anggraini. 2015. Hubungan Antara Pengetahuan Tentang HIV/AIDS dengan Niat Melakukan Voluntary Counseling and Testing (VCT) Pada Ibu Hamil di Puskesmas Gedong Tengen Yogyakarta
Tahun 2015. Yogyakarta: Stikes Aisyiyah Yogyakarta

Anggraini, A. 2014. Faktor-Faktor yang Mempengaruhi Prilaku Pemeriksaan VCT Pada Ibu Hamil Di Wilayah Kerja Puskesmas II Melaya Kabupaten Jembrana Provinsi Bali. Bali: STIKes Ngudi Waluyo Ungaran

Christiana, indah. 2015. Hubungan Peran Bidan Dengan Kepatuhan Pemeriksaan VCT (Voluntary Counseling And Testing) pada Ibu Hamil di Wilayah Kerja Puskesmas Gitik Kabupaten Banyuwangi. Banyuwangi : Stikes Banyuwangi

Dewi. 2013. Buku Ajar Kesehatan Reproduksi dan Keluarga Berencana. Jakarta : Trans Info Media

Dimissie, Abebai. 2009. Determinants Of Acceptance Of Voluntary HIV Testing Among Antenatal Clinic Attendees At Dil Chora Hospital, Dire Dawa, East Ethiopia. Ethiopia: Ethop. Health Dev

Dinas Kesehatan Sumbar. 2014. Komisi Penanggulangan AIDS Nasional. https://idid.facebook.com/perm alink.php?story_fbid Diakses tanggal 18 Februari 2016

Ditjen PP \& PL Kemenkes RI. 2014. Situasi dan Analisi HIV/ AIDS. Jakarta: Infoatin

Fanta, Wondimageg. 2008. Determinants for refusal of HIV testing among women attending for antenatal care in Gambella Region, Ethiopia. Ethiopia: PMC

Hidayat. 2008. Metode Penelitian Kebidanan Tekhnik Analisis 
Data. Jakarta : Salemba Medika.

2007. Metode Penelitian Kebidanan Tekhnik Analisis Data. Jakarta : Salemba Medika.

Hutapea, Ronald. 2011. AIDS \& PMS dan Perkosaan. Jakarta: Rineka Cipta

Kholid. 2014. Promosi Kesehatan. Jakarta: Rajawali Pers

Kementrian Kesehatan RI. 2014. Pedoman Nasional Pencegahan Anak Penularan HIV dari Ibu ke (PPIA).http://data.unaids.org/to pics/partnershipmenus/indonesiaresponseid.pdf diakses tanggal 17 februari 2016

Legiati, Titi. Prilaku Ibu Hamil dalam Tes HIV Di Kelurahan Bandarharjo dan Tanjung Mas Kota Semarang. Semarang : Jurnal Promosi Kesehatan

Maryanti. 2009. Buku Ajar Kesehatan Reproduksi Teori dan Praktikum.

Yogyakarta : Nuha Medika

Notoatmodjo. 2003. Pendidikan dan Perilaku Kesehatan. Jakarta : Renika Cipta 2005. Metodologi Penelitian Kesehatan. Jakarta : Rineka Cipta

2010. Metodologi Penelitian Kesehatan. Jakarta : Rineka Cipta

2005. Promosi Kesehatan Teori dan Aplikasi. Jakarta : Rineka Cipta

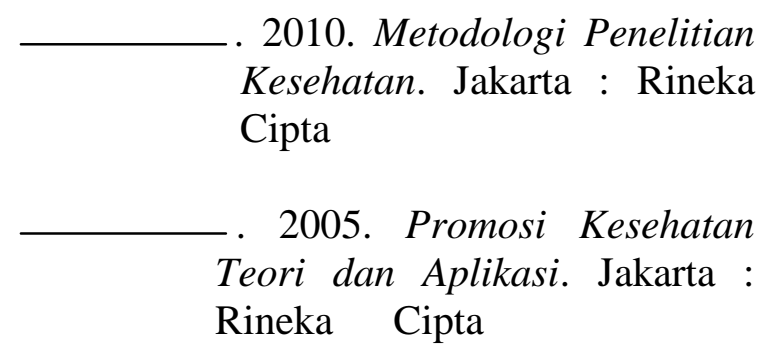

Nursalam, Ninuk Dian Kurniawati. 2014. Asuhan Keperawatan pada Pasien Terinfeksi HIV/AIDS. Jakarta: Salemba Medika

Rukiyah. 2010. Asuhan Kebidanan IV. Jakarta: Trans Info Media

Saydam. 2012. Waspadai Penyakit reproduksi Anda. Bandung : Pustaka Reka Cipta

Vitasari, Rizky Nur. 2014. Hubungan Tingkat Pengetahuan, Sikap Tentang PMS

Widyanto. 2013. Trend Disease. Jakarta : Trans Info Media dan Motivasi Bidan dengan Melakukan Tes Prevention Of Mother To Child Transmission Pada Ibu Hamil Di Puskesmas Campurejo Kota Kediri. Surakarta: Universitas Sebelas Maret

Wulansari, 2014. Faktor-Faktor yang berhubungan dengan Niat Ibu Hamil Untuk Memanfaatkan Layanan VCT di Wilayah Kerja Puskesmas Ciputat Kota Tangerang Selatan Provinsi Banten Tahun 2014. Jakarta: 